\title{
GROWTH AND TOXIN PRODUCTION OF TETANUS BACILLI IN VIVO
}

\author{
J. W. G. SMITH* AND A. G. MACIVER $\dagger$ \\ *Epidemiological Research Laboratory, Central Public Health Laboratory, Colindale Avenue, \\ London NW9 5HT, and †Department of Morbid Anatomy, Faculty of Medicine, \\ Southampton University
}

TET AN US spores will germinate and multiply in animal tissue provided that an area with a sufficiently low oxidation-reduction potential is present (Fildes, 1927). Although some factors that produce conditions suitable for growth in vivo are understood, information concerning the growth cycle of tetanus bacilli in tissues is limited. Under suitable conditions, outgrowth from tetanus spores and multiplication of vegetative forms may be observed very soon after spores are injected into the tissues. Dorothy Russell (1927) detected growth microscopically on the second day in necrotic foci produced when guinea-pigs were challenged with an intramuscular injection of earth and tetanus spores. In similar studies with calcium chloride as the devitalising agent, considerable numbers of vegetative forms could be seen at 24 hours after challenge. Fildes (1927) reported vegetative forms as early as 2 hours after spores were injected into the ligated testicle in guinea-pigs. The present study describes a quantitative examination of the multiplication of tetanus bacilli in mice, and the findings are related to evidence concerning the early formation of toxin in vivo.

\section{MATERIALS AND METHODS}

Clostridium tetani. A spore suspension of C. tetani strain T67 (NCTC540) was prepared in normal saline solution and heated at $80^{\circ} \mathrm{C}$ for $20 \mathrm{~min}$. to inactivate free toxin and vegetative bacilli, as described previously (Smith, 1964). The viable count, measured on blood agar plates, was $6 \times 10^{6}$ per $\mathrm{ml}$. The suspension had no effect on mice when $0.2 \mathrm{ml}$ was injected intramuscularly in the absence of $\mathrm{CaCl}_{2}$ solution. Moreover, two mice were unaffected by $2 \mathrm{ml}$ of the filtrate obtained by passing the suspension through a bacterial filter. The spore preparation was therefore assumed to contain no active toxin. The suspension was stored in the refrigerator at $0-4^{\circ} \mathrm{C}$ for 2 months before use. Just before an experiment, the following steps were taken. To disperse clumps of spores, the stored suspension was shaken vigorously and sucked up and expelled from a Pasteur pipette several times. Then a sample of the spore suspension was diluted in a standard volume of sterile Ringer's solution and the final dilution was made in an equal volume of $8 \% \mathrm{CaCl}_{2}$ solution, to give a final suspension in $4 \%$ $\mathrm{CaCl}_{2}$.

Tetanus toxin was prepared from a culture filtrate of $C$. tetani, strain T67, by precipitation with ammonium sulphate. The crude toxin was freeze-dried and stored in a vacuum desiccator over $\mathrm{P}_{2} \mathrm{O}_{5}$ at $0-4^{\circ} \mathrm{C}$. Dilutions for experimental use were prepared in a sterile aqueous solution of $0.1 \%$ peptone (Difco) with $0.85 \% \mathrm{NaCl}$. The LD50 of the preparation for the test mice was $0.00038 \mathrm{mg}$.

Tetanus in mice. Male albino mice weighing $16-20 \mathrm{~g}$ were used. Tetanus toxin, or spores in $\mathrm{CaCl}_{2}$ solution, were injected into the right hind leg. The mice were observed at intervals

Received 9 Apr. 1974; accepted 4 May 1974.

J. MED. MICROBIOL.-VOL. 7 (1974) 
afterwards to record the development and progress of the resulting ascending tetanus. Mice were killed as soon as it was judged that the tetanus was sure to cause death ("fatal tetanus ").

Infection of mice. Fur overlying the muscles of the right thigh was removed by shaving and the exposed skin was treated with tincture of iodine for $2 \mathrm{~min}$. Infection was induced by an intramuscular injection through the prepared area of $0.2 \mathrm{ml}$ of a mixture of equal volumes of freshly prepared and autoclaved $8 \% \mathrm{CaCl}_{2}$ solution and a dilution of the spore suspension. In the viable-count experiments the number of spores was about 4000 colony-forming units; this dose was equivalent to approximately 500 LD50 or 30 MLD.

C. tetani in lesions. Mice were killed by stunning and immersed in 3\% lysol solution for $2 \mathrm{~min}$. With aseptic precautions, the affected hind leg was immediately dissected to remove the $\mathrm{CaCl}_{2}$ lesion from surrounding healthy tissues. The lesion was trimmed so that only a narrow rim of normal tissue was left attached. It was then washed three times in sterile Ringer's solution and put into a sterile graduated tube containing $2.0 \mathrm{ml}$ of thioglycollate broth. The volume of the excised lesion was measured by displacement.

Each excised lesion in broth was ground in a mortar with a pestle and sterile sand to produce a smooth paste within 2-3 min. Dilutions of the macerate were prepared in thioglycollate broth and viable counts were made.

Viable counts. The number of viable organisms in the spore suspension or in tissue macerate was estimated by spreading $0 \cdot 1-\mathrm{ml}$ volumes, in duplicate, on firm horse-blood agar (i.e., $4 \%$ agar to inhibit swarming). The plates were incubated anaerobically with $10 \% \mathrm{CO}_{2}$ for 4 days, when colony-counts were made from plates containing about 200 colonies. No attempt was made to activate the spores before counting, as the primary object was to detect " natural " outgrowth. To ensure that the growth of the tetanus bacilli in vivo had not been affected by other competing bacteria, the undiluted paste was cultured aerobically and anaerobically on horse-blood agar, and Gram-stained slides for microscopy were prepared. Results were discarded when the lesion paste yielded growth of bacteria other than C. tetani within $\mathbf{4 8}$ hours, or if microscopy showed bacterial forms that did not appear to be C. tetani. With the methods described, contamination was detected in only about $5 \%$ of experiments.

Viable counts measured on the surface of agar plates as described above are referred to in the Results section of the present paper; the procedure has been found (Smith, 1966) to give about a 5-fold lower estimate of the number of viable organisms than that derived from counts obtained by quantal response procedures with Brewer's broth, and about a 4-fold lower estimate than that based on counts of colonies in Brewer's medium containing $0.25 \%$ agar.

\section{RESULTS}

\section{Recovery of C. tetani from the injection site}

Preliminary experiments were made as follows to estimate the efficiency with which the injected spores could be recovered:

(i) Before each experiment, viable counts were made on the freshly prepared suspension of spores in $\mathrm{CaCl}_{2}$ solution ready for injection. The mean count was $3.75 \times 10^{3}$ per $0 \cdot 2-\mathrm{ml}$ dose; no fall in the count was detected over the 4-month period in which the experiments were made.

(ii) To examine the effect of the grinding process on the spores, the inoculum was added to $2.0 \mathrm{ml}$ of thioglycollate broth and ground up with sterile sand in the manner described for the lesions. A viable count on the ground material gave $2.9 \times 10^{3}$ colony-forming units per $0.2 \mathrm{ml}$. The grinding process thus caused a 1.3-fold loss in the number of spores that could be counted. The possibility was also examined that a considerable loss of vegetative bacilli might also result from the grinding process. Dilutions of a 24-hour cooked-meat broth culture of the $C$. tetani strain were 
made in thioglycollate broth and ground with sand. Further dilutions were prepared from the original and the ground-up diluted samples, and viable counts were made. The findings showed that the loss of vegetative bacilli from a 24-hour culture was slightly greater than that of the spores, i.e., approximately $1 \cdot 8$-fold. This factor has been disregarded in the results given below on growth in vivo.

(iii) Replicate inocula were injected into hind-leg musculature exposed in dead mice; some of the inoculum could be seen to leak out from the muscles immediately. In the intact animal this material would presumably be dispered in the subcutaneous tissues. The challenge area was excised and ground with sand and counts were made as described in the Methods section.

TABLE I

Growth of tetanus bacilli in vivo after injection of approximately 3750 spores in $0.2 \mathrm{ml}$ of $4 \%$ $\mathrm{CaCl}_{2}$ solution

\begin{tabular}{|c|c|c|c|c|}
\hline $\begin{array}{l}\text { Time interval (hours) } \\
\text { after inoculation }\end{array}$ & $\begin{array}{c}\text { Number of lesions } \\
\text { examined }\end{array}$ & $\begin{array}{l}\text { Mean volume } \\
\text { of lesions (ml) }\end{array}$ & $\begin{array}{l}\text { Mean viable } \\
\text { count* }^{*}\end{array}$ & $\begin{array}{l}\text { Range of } \\
\text { viable count* }\end{array}$ \\
\hline $\begin{array}{r}\frac{1}{2} \\
6 \\
12 \\
18 \\
24 \\
32 \\
42 \\
48\end{array}$ & $\begin{array}{l}4 \\
9 \\
6 \\
5 \\
4 \\
4 \\
4 \\
4\end{array}$ & $\begin{array}{l}0 \cdot 4 \\
1 \cdot 0 \\
1 \cdot 1 \\
1 \cdot 2 \\
1 \cdot 0 \\
1 \cdot 0 \\
1 \cdot 0 \\
1 \cdot 2\end{array}$ & $\begin{array}{l}8.6 \times 10^{2} \\
4.0 \times 10^{2} \\
1 \cdot 2 \times 10^{3} \\
1.7 \times 10^{5} \\
6.8 \times 10^{6} \\
3.3 \times 10^{66} \\
1 \cdot 2 \times 10^{7} \\
4.0 \times 10^{6}\end{array}$ & $\begin{array}{l}\left(7 \cdot 1 \times 10^{2}\right)-\left(1.1 \times 10^{3}\right) \\
\left(1.1 \times 10^{2}\right)-\left(9.6 \times 10^{2}\right) \\
\left(3.1 \times 10^{2}\right)-\left(2.0 \times 10^{5}\right) \\
\left(1.2 \times 10^{4}\right)-\left(6.6 \times 10^{5}\right) \\
\left(2.9 \times 10^{4}\right)-\left(2.0 \times 10^{7}\right) \\
\left(9.3 \times 10^{5}\right)-\left(6.8 \times 10^{6}\right) \\
\left(3.0 \times 10^{3}\right)-\left(4.3 \times 10^{7}\right) \\
\left(1.6 \times 10^{4}\right)-\left(1.5 \times 10^{7}\right)\end{array}$ \\
\hline
\end{tabular}

* Viable count given as total number of colony-forming units present in excised lesions, as determined by colony counts on blood agar plates containing $4 \%$ agar.

The number of spores recovered from the exposed (dead) mucles that had received the challenge in vitro varied in four experiments between $1.2 \times 10^{3}$ and $2.9 \times 10^{3}$ with a mean of $2 \cdot 1 \times 10^{3}$; thus, $28 \%$ of the inoculum is assumed to have been lost by leakage.

(iv) Similar studies were done in vivo, the (viable) muscles of the leg being examined between 20 and $30 \mathrm{~min}$. after challenge. The mean number of spores then recovered was $8.6 \times 10^{2}$, so that a further $59 \%$ of the spores was lost within $30 \mathrm{~min}$. of injection. This additional loss is perhaps accounted for by escape of spores mechanically squeezed from the muscles by leg movement, by loss through the lymphatics, and by phagocytosis. Whatever the mechanism, however, the effect was that only about 1000 spores apparently remained available to grow in the injection area.

\section{Growth of C. tetani in vivo}

The growth in vivo of the inoculum of $C$. tetani, suspended in $\mathrm{CaCl}_{2}$ solution to induce tissue necrosis, was followed in mice examined at different times after challenge. The results are given in table I. At $30 \mathrm{~min}$. after injection the lesion could not be clearly seen macroscopically, but by 6 hours a focus could 
be defined, the volume of which was about $1.0 \mathrm{ml}$ (range $0.4-1.4 \mathrm{ml}$ ). The lesion subsequently became more clearly delineated from the surrounding healthy tissues and became more uniform in size in different animals; most lesions were $0.9-1.3 \mathrm{ml}$ in volume.

The counts indicate that there was loss of viable organisms between $30 \mathrm{~min}$. and 6 hours after challenge, but the numbers subsequently increased rapidly to reach a peak of about $2 \times 10^{7}$ colony-forming units per lesion at $24-48$ hours.

\section{Studies of experimental tetanus in mice}

Effect of challenge with tetanus toxin. Groups of mice were challenged by subcutaneous injection into the right hind leg of $0.5 \mathrm{ml}$ of a series of doubling dilutions of tetanus toxin, the initial dilution containing $0.01 \mathrm{mg}$ of toxin in

TABLE II

The time course of the development of tetanus in mice challenged with toxin

\begin{tabular}{|c|c|c|c|c|c|}
\hline \multicolumn{2}{|c|}{ Dose of toxin } & \multirow{2}{*}{$\begin{array}{l}\text { Number of survivors/ } \\
\text { number challenged }\end{array}$} & \multirow{2}{*}{$\begin{array}{l}\text { Mean time to } \\
\text { onset of } \\
\text { tetanus (hours) }\end{array}$} & \multirow{2}{*}{$\begin{array}{l}\text { Mean time to } \\
\text { " fatal tetanus" } \\
\text { (hours) }\end{array}$} & \multirow{2}{*}{$\begin{array}{l}\text { Interval between } \\
\text { onset and "fatal } \\
\text { tetanus" (hours) }\end{array}$} \\
\hline $\mathrm{mg}$ & MLD & & & & \\
\hline $\begin{array}{l}0.01 \\
0.005 \\
0.0025 \\
0.0013 \\
0.00063 \\
0.00031 \\
0.00016\end{array}$ & $\begin{array}{l}16 \\
8 \\
4 \\
2 \\
1 \\
0.5 \\
0.25\end{array}$ & $\begin{array}{l}0 / 8 \\
0 / 8 \\
0 / 8 \\
0 / 8 \\
0 / 8 \\
6 / 8 \\
8 / 8\end{array}$ & $\begin{array}{l}10 \\
10 \\
12 \\
13 \\
30 \\
36 \\
48\end{array}$ & $\begin{array}{l}22 \\
23 \\
27 \\
30 \\
78 \\
\ldots \\
\ldots\end{array}$ & $\begin{array}{l}12 \\
13 \\
15 \\
17 \\
48 \\
\ldots \\
\ldots\end{array}$ \\
\hline
\end{tabular}

$* \mathrm{MLD}=0.00063 \mathrm{mg} ; \mathrm{LD} 50=0.00038 \mathrm{mg}$.

$\dagger$ "Fatal tetanus" = severity judged to be inevitably fatal.

$0.5 \mathrm{ml}$. The mice were observed at approximately hourly intervals in order to record the first appearance of signs of tetanus and the progression of the disease. The results are given in table II.

The minimum lethal dose of toxin $(0.00063 \mathrm{mg})$ caused the first sign of tetanus to be visible on average 30 hours after injection, with progression to a state judged sure to be fatal ("fatal tetanus ") at 78 hours. However, all the larger doses up to $0.01 \mathrm{mg}(16 \mathrm{MLD})$ caused the first signs of tetanus to appear within a fairly short time range-from 13 hours ( $0.0013 \mathrm{mg}, 2 \mathrm{MLD})$ to 10 hours ( $0.01 \mathrm{mg}, 16 \mathrm{MLD})$, and the times to progress to " fatal tetanus "were also spread over a short time range-from 17 to 12 hours.

Effect of challenge with C. tetani spores. Groups of mice received an intramuscular injection of a series of dilutions of tetanus spores suspended in $4 \%$ $\mathrm{CaCl}_{2}$ solution, and the development of tetanus was similarly observed; the results are given in table III. When small number of spores (too few to cause tetanus in all mice) were injected, an appreciable delay in onset and progress of the disease was evident in some affected animals, although in others the tetanus appeared rapidly. A dose of 1 MLD of viable spores (120 colony-forming units) allowed tetanus to develop within about 28 hours after challenge to reach 
the "fatal tetanus" stage about 20 hours later. More severe challenges with larger numbers of spores (1,200-120,000 colony-forming units) all produced a similar picture: signs of tetanus developed approximately 20 hours after injection and progressed to " fatal tetanus" about 18-16 hours later. Although the time interval from challenge to onset of symptoms was different in mice given toxin and those given spores, the course of the disease produced by 120 120,000 spores was similar to that observed when 2 MLD of toxin was injected (see table III). The time difference between the onset of tetanus after the injection of spores and that after 2 MLD of toxin may therefore represent the time for 2 MLD of toxin to be released in the wound by germinating spores.

TABLE III

The time course of the development of tetanus in mice infected with spores given intramuscularly in $0.2 \mathrm{ml}$ of $4 \% \mathrm{CaCl}_{2}$ solution

\begin{tabular}{c|r|c|c|c|c}
\hline $\begin{array}{c}\text { Dilution of } \\
\text { spore } \\
\text { suspension }\end{array}$ & $\begin{array}{c}\text { Number of } \\
\text { spores } \\
\text { injected* }\end{array}$ & $\begin{array}{c}\text { Number of } \\
\text { survivors/number } \\
\text { challenged }\end{array}$ & $\begin{array}{c}\text { Mean time } \\
\text { to onset of } \\
\text { tetanus (hours) }\end{array}$ & $\begin{array}{c}\text { Mean time to } \\
\text { "fatal tetanus " } \\
\text { (hours) }\end{array}$ & $\begin{array}{c}\text { Interval between } \\
\text { onset and " fatal } \\
\text { tetanus " (hours) }\end{array}$ \\
\hline 101 & 120,000 & $0 / 6$ & 20 & 36 & 16 \\
102 & 12,000 & $0 / 6$ & 20 & 38 & 18 \\
$10^{03}$ & 1,200 & $0 / 6$ & 20 & 38 & 18 \\
$10^{4}$ & 120 & $0 / 6$ & 28 & 48 & 55 \\
105 & 12 & $2 / 6$ & 39 & 96 & $\cdots$ \\
\hline
\end{tabular}

* Counts based on a viable count procedure (see Methods): 1 MLD $=120$ viable colonyforming units; LD50 = 7 viable colony-forming units.

$\dagger$ "Fatal tetanus" = severity judged to be inevitably fatal.

\section{Discussion}

These experimental findings showed that a rapid, probably logarithmic, growth phase resulted between 6 and 24 hours after injection of tetanus spores suspended in calcium chloride solution into the muscles of mice. This rapid growth produced, in a lesion of about $1.0 \mathrm{ml}$ in volume which was surrounded by healthy oxygenated tissues, as many as $2 \times 10^{7}$ viable organisms within 24 hours. Little information exists on the relation of this in vivo growth cycle to the production of toxin. Francis (1914) estimated that more than 1000 lethal doses of toxin were present in the tissues of guinea-pigs experimentally infected with tetanus; the report is based on tests of saline extracts of tissues taken from animals on the point of death. Payling Wright (1955) remarked that since signs of tetanus may appear within 2 or 3 days of infection in experimental animals, and occasionally in man, multiplication of the bacteria in the tissues must be followed promptly by the release of toxin. In the early stages of the growth cycle the formation of toxin in vivo may not be directly detectable. Thus we could not detect toxin in saline extracts of lesions from mice or guinea-pigs taken 6 and 12 hours after infection; presumably the toxin produced early is immediately fixed to the tissues. However, indirect evidence suggests that toxin formation may begin soon after infection. 
It is possible to prevent tetanus in mice challenged intramuscularly with spores in calcium chloride solution if penicillin is given 4 hours but not 8 hours after the challenge (Smith, 1964). Failure of penicillin to prevent tetanus when given 8 hours after experimental infection is unlikely to be due to a failure of antibiotic to reach the organisms, because evidence exists that penicillin given 15 hours or 4 days after infection will prevent further growth of tetanus bacilli at the injection site (Smith and MacIver, 1969). These observations suggest that a lethal dose of toxin may be formed in mice between 4 and 8 hours after the initiation of infection. Futher evidence that toxin may be formed early after infection is provided by the results reported here: (i) the first signs of tetanus appeared at 13-10 hours in mice challenged with 2-16 MLD of toxin, with progression to "fatal tetanus" 17-12 hours later; and (ii) the mean time of onset of tetanus was 28 hours after challenge with 120 spores (1 MLD) and 20 hours after challenge with from 1200 to 120,000 toxin-free spores. Progression from onset to "fatal tetanus" required 20-16 hours.

Strict comparison between the latter two situations is not possible, because the release of toxin in infected mice is presumably progressive. Nevertheless, a comparison of the findings indicates that the 20 -hour period required for the disease to progress from first signs to "fatal tetanus" in mice infected with from 120-120,000 spores was similar to the mean time in mice given 2 MLD of toxin. Thus 2 MLD of toxin appeared to reproduce the course of the disease seen in the infected mice. The difference in time between the onset of tetanus in infected mice and that in animals given 2 MLD of toxin may therefore indicate the time taken for about 2 MLD of toxin to be formed, i.e., about 15 hours by 1 MLD of spores and about 7 hours by all the spore challenges that exceeded 1 MLD.

The early production of toxin may be related to the in-vivo growth cycle observed when approximately 3750 spores were injected, of which 860 were locally retained. A plot of the data given in table I indicates that the number of viable $C$. tetani in the lesion at 7 hours was about 480 colony-forming units. However, the results of our preliminary experiments indicated that a loss of viable organisms of the order of 1.8 -fold occurred in the preparation process; thus the count of $C$. tetani at 7 hours should be $480 \times 1.8(=864)$ colonyforming units. Within 24 hours, counts of $2 \times 10^{7}$ organisms may be obtained, and it therefore seems likely that very large amounts of toxin may be produced from a small lesion of only about 1 -ml volume.

Evidence from studies with another toxigenic member of the Clostridium genus, namely $C$. botulinum, raises the possibility that the tetanus that we observed in experimentally infected mice could have been due to pre-formed toxin, rather than to new toxin produced by the growing organisms. Thus, botulism may be produced in mice by intraperitoneal injection of $C$. botulinum spores without a devitalising agent (Suzuki et al., 1971). The spores have been shown to germinate within phagocytes, but outgrowth of the spores apparently does not occur (Suzuki and Grecz, 1972), and the toxin responsible for the botulism is believed to be pre-formed within the spore. Indeed, Keppie (1951) showed that $C$. botulinum toxin could be extracted from non-germinating 
spores. Although the possibility that toxin may also exist pre-formed in tetanus spores is open to further study, the following points suggest that it is unlikely to have been a factor. (i) Our experiments were performed with spore challenges ranging from 12-120,000 spores; a dose as small as 120 spores (counted on agar plates) was consistently fatal. Although it is not possible to compare $C$. botulinum spores directly with tetanus spores, the challenge dose of $C$. botulinum spores needed to cause illness in mice as a result of pre-formed toxin was large. Booth et al. (1972) found that a dose of 500,000 spores, counted by a quantal response method, was required in order to kill 9 of 10 mice weighing $20 \mathrm{~g}$. (ii) Tetanus produced by injection of a dose of 3000 spores in mice could not be attributed by Shoesmith (1964) to pre-formed toxin. (iii) In the present study, the intramuscular injection of $0.2 \mathrm{ml}$ of the tetanus-spore suspension (without $\mathrm{CaCl}_{2}$ ), containing about $1,200,000$ spores, was innocuous to mice. However, we have not yet investigated whether such spores undergo lysis and further work would be necessary to establish beyond doubt that no pre-formed toxin existed.

If necrotic human muscle does not differ from mouse muscle in its ability to support growth and toxin formation of $C$. tetani, the present findings may have practical implications in relation to prophylaxis of tetanus in man. From the practical point of view it is probably advisable to regard a wound in a patient not seen until 6-7 hours after injury as already potentially the source of a significant amount of toxin. At 24 hours, a lesion may well have been the site of production of a considerable amount of toxin. In various series of cases of tetanus reported in recent years, no site of infection was found in as many as $20 \%$ of patients (see, for example, Vakil et al., 1965). The difficulty of detecting a lesion in such cases is perhaps explained both by the extreme potency of tetanus toxin and by the fact that a lesion only $1 \mathrm{ml}$ in volume may support a heavy growth of tetanus bacilli producing more than enough toxin to precipitate the disease.

\section{SUMMARY}

The vegetative growth of tetanus bacilli in vivo was examined in mice challenged intramuscularly with spores suspended in $4 \% \mathrm{CaCl}_{2}$ solution. The viable count of organisms in material derived by grinding up the injection site was low at 6 hours and thereafter increased to counts of the order of $2 \times 10^{7}$ colony-forming units of Clostridium tetani in the ground-up lesion about 24 hours after inoculation. At that time the lesion volume was only about $1 \mathrm{ml}$.

In mice challenged with 1200 to 120,000 spores or in those given 2 MLD of toxin, the time taken for the resulting ascending tetanus to progress from its first appearance to become severe enough to prove fatal was similar-about 17 hours. For the infected mice and those challenged with toxin, however, the time of onset of the first signs of tetanus differed: it was 13 hours after inoculation of toxin, but 20 hours after injection of spores. It is suggested that the difference represents the time taken for the injected spores to form 2 MLD of toxin in the mouse, i.e., about 7 hours after challenge. At this time the numbers 
of viable organisms at the site of infection had not detectably increased, but rapid growth was about to begin.

These observations suggest that a lethal dose of tetanus toxin may be produced rapidly in an infected tissue by a very small number of viable organisms. Within 24 hours of challenge, a heavy growth of $C$. tetani may be present in a lesion only about $1 \mathrm{ml}$ in volume.

The authors are grateful for laboratory facilities kindly provided in the Bacteriology Department, Radcliffe Infirmary, Oxford, and they thank Dr Betty Hobbs and Dr Richard Gilbert for facilities provided in the Food Hygiene Laboratory, Colindale.

\section{REFERENCES}

Booth, R., Suzuki, J. B., Berg, B. E. AND GRECZ, N. 1972. Influence of weight and sex of mice in assaying spore-bound Clostridium botulinum type A toxin. J. Fd Sci., 37, 183.

FILDES, P. 1927. Tetanus. VI The conditions under which tetanus spores germinate in vivo. Br.J. exp. Path., 8, 387.

Francis, E. 1914. Laboratory studies on tetanus. Hygiene Laboratory Bulletin no. 95, U.S. Public Health Service, Washington.

KEPPIE, J. 1951. The pathogenicity of the spores of Clostridium botulinum. J. Hyg., Camb., 49, 36.

Russell, D. S. 1927. Tetanus. V. The local fate of tetanus spores inoculated into guineapigs. Br. J. exp. Path., 8, 377.

Shoesmith, J. G. 1964. The effect of heat and radiation on the viability and pathogenicity of Clostridium tetani. J. gen. Microbiol., 35, vi.

SMITH, J. W. G. 1964. Penicillin in prevention of tetanus. Br. med. J., 2, 1293.

SMITH, J. W. G. 1966. In Studies in prophylaxis and treatment of tetanus, M.D. Thesis, University of Wales, p. 269.

SMith, J. W. G. AND MacIVer, A. G. 1969. Studies in experimental tetanus infection. $J$. med. Microbiol., 2, 385.

Suzuki, J. B., Booth, R., Benedik, A. ANd Grecz, N. 1971. Pathogenesis of Clostridium botulinum, type A. Study of in vivo toxin release by implantation of diffusion chambers containing spores, vegetative cells and free toxin. Infect. Immun., 3, 659.

SuzuKI, J. B. AND Grecz, N. 1972. Electron microscopy and leukocyte interaction with spores of Clostridium botulinum type A. Can. J. Microbiol., 18, 1651.

Vakil, B. J., Aiyar, S. N., Tulpule, A. T., Mehta, A. J. ANd Tulpule, T. H. 1965. A study of 2130 cases of tetanus with special reference to incidence, clinical types and prognosis. In Proceedings of the First International Conference on Tetanus, Bombay, 1963, edited by J. C. Patel, Bombay, p. 54.

WrIGHT, G. P. 1955. The neurotoxins of Clostridium botulinum and Clostridium tetani. Pharmac. Rev., 7, 413. 